\title{
The Polish version of the Montreal Children's Hospital Feeding Scale (MCH-FS): translation, cross-cultural adaptation, and validation
}

\author{
Katarzyna Bąbik ${ }^{1,2}$, Piotr Dziechciarz², Andrea Horvath², Paweł Ostaszewski \\ 'Faculty of Psychology, University of Social Sciences and Humanities, Warsaw, Poland \\ ${ }^{2}$ Department of Paediatrics, Medical University of Warsaw, Warsaw, Poland
}

\section{ABSTRACT}

Aim of the study: To provide a reliable and valid tool in Polish language for assessing the level of feeding difficulties among children from six months up to six years old by translation, cross-cultural adaptation, and validation of the Montreal Children's Hospital Feeding Scale (MCH-FS).

Material and methods: The translation and cross-cultural adaptation included: forward translation (by two independent translators), comparison of the two translated versions, blind back translation, comparison of the two back-translated versions, pilot testing, proofreading, and approval of the final version of the target language.

Results: To establish construct validity, 247 parents or caregivers of children completed the scale. The clinical sample included parents/caregivers $(n=124)$ of children referred to a feeding clinic, whereas the normative sample $(n=123)$ consisted of parents/caregivers of healthy children recruited from daycare centres. Statistically significant differences were found between the control group and children with feeding disorders for the total score $(p<0.001)$ and for each of the 14 items $(p<0.001)$. The instrument has strong internal consistency ( $\alpha=0.93$ ). Test-retest reliability was obtained by re-administration of the MCH-FS to 84 subjects within a mean interval of 13.43 days. Test-retest correlation coefficients for the total score of the MCH-FS were 0.98 in the clinical group and in the normative group $(p<0.001)$, suggesting a high level of tool stability.

Discussion: The Polish version of the MCH-FS can be considered as a reliable and valid tool for screening the feeding difficulties in children.

\section{KEY WORDS:}

feeding difficulties, validation study, feeding scale.

\section{INTRODUCTION}

A number of standardised instruments have been developed to facilitate the identification of feeding difficulties [1]. One of the most widely used is the Montreal Children's Hospital Feeding Scale (MCH-FS). The MCHFS consists of 14 items involving feeding areas such as: mealtime behaviours, oral sensory, oral motor, appetite, parental concerns about feeding, parental strategies used, and family reactions to the child's feeding [2]. The scale targets children from six months to six years old. Each question is rated on a seven-point Likert scale. The total score is obtained by adding the scores from each item. The scale takes approximately five minutes to complete. The MCH-FS in its original English version was validated among children with and without feeding problems. So

\section{ADDRESS FOR CORRESPONDENCE:}

Katarzyna Bąbik, Faculty of Psychology, University of Social Sciences and Humanities, 19/31 Chodakowska St., 03-815 Warsaw, Poland, ORCID: 0000-0002-8469-2440, e-mail: katarzyna.babik@gmail.com 
far, the scale has been translated, adapted, and validated in French [2], Thai [3], Portuguese [4], and Dutch [5]. Until now there has been no published scale in the Polish language for the screening of feeding difficulties. A translated scale will provide a tool for quick detection of feeding difficulties among children, which would be beneficial for the administration of appropriate support and help.

The aim of our study was to translate into Polish, cross-culturally adapt, and validate the MCH-FS.

\section{MATERIAL AND METHODS}

The translation and cultural adaptation of the $\mathrm{MCH}$ SF was performed according to published guidelines [6]. Steps included:

1) forward translation by two independent translators,

2) comparison of the two translated versions,

3) blind back translation,

4) comparison of the two back-translated versions,

5) pilot testing, proofreading, and approval of the final version of the target language version.

\section{STEP 1: FORWARD TRANSLATION}

The scale was translated from English into Polish by two independent, bilingual translators whose mother language is Polish and who are fluent in both languages: an expert in psychology and an expert in medicine.

\section{STEP 2: COMPARISON OF THE TWO TRANSLATED VERSIONS OF THE INSTRUMENT - SYNTHESIS I}

After the forward translation an expert panel convened in order to analyse the original version of the scale and both translations. A multi-disciplinary committee was composed of translators (2), an independent translator (1), paediatricians (4), gastroenterologists (2), a nutritionist (1), a speech therapist (1), and a psychologist (1), who were not directly involved in the translation process. In this phase, one version of the scale in Polish was created.

\section{STEP 3: BLIND BACK TRANSLATION}

The Polish translation was translated back into English by two bilingual experts whose mother language is English and who are fluent in both languages. One of the translators was an expert in psychology. Neither translator was familiar with the original scale.

\section{STEP 4: COMPARISON OF THE TWO TRANSLATED VERSIONS OF THE INSTRUMENT - SYNTHESIS II}

A multi-disciplinary committee compared the original and translated versions of the scale. The semantics, grammar, and adaptation to Polish culture and language were analysed in order to create one version of the scale.

\section{STEP 5: PILOT TESTING, PROOFREADING, AND CREATING THE FINAL VERSION OF MONTREAL CHILDREN'S HOSPITAL FEEDING SCALE}

The Polish version of the tool was introduced to 30 mothers whose children were between age six months and six years old, in order to verify potential problems with understanding the questions. The reports of each translation phase and the results of the pilot testing were presented to the multi-disciplinary committee (three paediatricians, three psychologists, and three adults whose profession was not related to the medical or psychological filed). The final Polish version of the scale (Skala $\mathrm{MCH}$ związana z karmieniem dziecka - wersja polska), which was used in the further validation, was created after reviewing the translations and taking into account the comments of the participants who took part in the pilot testing phase. The MCH-FS in Polish is available in Appendix 1.

To determine the validity and reliability of the Polish translation of the MCH-FS, the participants and parents/ caregivers of children between six months and six years old were assigned into one of the following groups: normative or clinical. The clinical group represented parents/ caregivers of children with feeding difficulties (feeding disorders, feeding selectivity, and food refusal). They were recruited from a hospital-based multidisciplinary feeding difficulties clinic and were classified by a minimum of two specialists according to the diagnostic criteria included in the International Classification of Disease (F 98.2, ICD-10) and Diagnostic and Statistical Manual of Mental Disorders (307.59, DSM-V). Participants from the normative group were recruited from daycare centres in Warsaw. The parent/caregiver who was the child's primary feeder participated in the research. Exclusion criteria were as follows: chronic diseases and/or birth defects that may lead to impaired nutritional status, exclusive breast-feeding, and nasogastric tube (NG-tube) or gastrostomy tube (G-tube) dependence. All available subjects were asked to fill in the questionnaire for a second time two weeks after the first evaluation, to assess the test-retest reliability. In addition to demographic information, each child had weight and length/height assessment. Written, informed consent to participate in a study was obtained. Permission to use the MCH-SF for the translation into Polish, validation, and adaptation was obtained from the copyright holder, Ramsay Ltd. The Ethics Committee of the Medical University of Warsaw approved the study (AKBE/86/16). This research was supported by the NUTRICIA Foundation (grant no. RG 7/2016).

\section{STATISTICAL ANALYSIS}

Data were analysed using IBM SPSS Statistics (version 24). Calculation of the sample size was based on the assumption that there should be at least eight subjects 
per item per group. It was calculated that there should be a minimum of 123 participants per group when taking into consideration a $10 \%$ drop-out rate. Cronbach's a was calculated to determinate the internal consistency of the scale. For construct validity, the total and individual item scores were compared among the groups by using Student's $t$-test. Cohens $d$ for $t$ test was calculated. Receiver Operating Characteristic (ROC) analysis was performed to evaluate the sensitivity and specificity of the tool. The Kaiser-Meyer-Olkin (KMO) and Bartlett's test of sphericity $\chi$ were calculated to assess suitability of the dataset for the basis of principal component analysis (PCA). A PCA with Varimax rotation, using Kaiser's criterion, was conducted to investigate the factor structure of the MCH-FS. Sample size calculation for the retest was derived from the formula of the Intraclass Correlation Coefficient (ICC) test. A minimum sample size of 45 was sufficient to detect a value of 0.40 for the ICC ( $\alpha$ and power were fixed at 0.05 and lower than $80 \%$, respectively), and consideration of a $20 \%$ of drop-out rate [7]. Pearson's correlation coefficients were calculated for the total scores of the translated $\mathrm{MCH}-\mathrm{FS}$ between initial scores and scores obtained on average two weeks later for test-retest reliability. Descriptive statistics were used to describe the study population characteristics. As recommended by the World Health Organisation (WHO), the children's weight, length/ height, and body mass index (BMI) were converted into standard deviation scores ( $z$-scores). WHO Anthro (0-5 years) and WHO AnthroPlus (5-19 years) software were used for the $z$-score calculations.

\section{RESULTS}

\section{STEP 6: VALIDATION - PSYCHOMETRIC PROPERTIES OF THE POLISH VERSION OF THE MONTREAL CHILDREN'S HOSPITAL FEEDING SCALE}

In order to assess the accuracy and reliability of the Polish translation of MCH-FS, 247 parents or caregivers of children aged six months to six years were recruited to the validation study between May 2017 and November 2018 (124 in the clinical group and 123 in the normative group). All participants were asked to complete the MCH-FS. Subsequently, randomly selected parents or caregivers were asked to complete the questionnaire for a second time two weeks later, to assess the reliability of the scale. In addition, basic anthropometric measurements (body weight, length/height) were performed for each recruited child. Characteristics of children for the normative and clinical groups are presented in Table 1.

\section{PSYCHOMETRIC PROPERTIES OF THE MONTREAL CHILDREN'S HOSPITAL FEEDING SCALE}

The results of analyses (Table 2) showed that the $\mathrm{MCH}-\mathrm{FS}$ discriminated significantly children with feeding difficulties and without feeding difficulties in total score $(p<0.001)$, as well as in all of the 14 items $(p<0.001)$. The instrument has strong internal consistency with a high Cronbach's $\alpha$, at 0.93 (95\% CI: 0.92 to $0.94)$. The area under the ROC curve is 0.99 , suggesting excellent accuracy (95\% CI: 0.99 to $1.00 ; p<0.001)$. A total score of 46 as the discrimination score demonstrated excellent sensitivity (89.5\%) and specificity (99.2\%). The KMO measures verified the sampling adequacy $(\mathrm{MSA}=0.94)$, and Bartlett's test of sphericity $\chi^{2}(91)=$ $2351.14, p<0.001$, indicating satisfactorily strong correlations between items. The analysis indicated two factors explaining $61.82 \%$ of the variance. The factor loadings, mean, and skewness are listed in Table 3. The correlation between both factors was high at 0.62 .

\section{TEST-RETEST RELIABILITY}

A total of 84 parents/caregivers (36 subjects from the clinical group and 48 subjects from the normative group) took a part in the test-retest assessment within a mean interval of 13.43 days ( $\mathrm{SD}=2.97$, range: 5 to 19 ). Correlation coefficients for the total score of the MCH-FS were 0.98 in both groups (clinical and normative) at $p<0.001$

TABLE 1. Characteristics of the normative and clinical groups

\begin{tabular}{|c|c|c|c|c|c|}
\hline Characteristic & $\begin{array}{c}\text { Normative } \\
(n=123) \\
\text { Mean } \pm \text { SD }\end{array}$ & $\begin{array}{c}\text { Clinical } \\
(n=124) \\
\text { Mean } \pm \text { SD }\end{array}$ & Fvalue $^{\mathrm{a}}$ & $\begin{array}{c}t(245) \\
p \text { values }^{\mathrm{a}}\end{array}$ & $95 \% \mathrm{Cl}$ \\
\hline Age, months & $42.08 \pm 20.25$ & $28.26 \pm 19.12$ & 0.55 & $-5.52^{*}$ & $-18.76 ;-8.89$ \\
\hline Length/height, z-score & $0.65 \pm 1.37$ & $-0.51 \pm 1.34$ & 0.33 & $-6.73^{*}$ & $-1.50 ;-0.82$ \\
\hline Weight, z-score & $0.26 \pm 1.02$ & $-1.00 \pm 1.10$ & 0.22 & $-9.26^{*}$ & $-1.52 ;-0.98$ \\
\hline BMI, z-score & $-0.19 \pm 1.22$ & $-1.00 \pm 1.06$ & 1.82 & $-5.49^{*}$ & $-1.09 ;-0.51$ \\
\hline \multicolumn{6}{|l|}{ Gender, $n(\%)^{b}$} \\
\hline Boys & $56(22.67)$ & $68(27.53)$ & & & \\
\hline Girls & 67 (27.13) & $56(22.67)$ & & & \\
\hline
\end{tabular}


TABLE 2. Differences in Montreal Children's Hospital Feeding Scale (MCH-FS) scores in children with feeding difficulties versus children without feeding difficulties

\begin{tabular}{|c|c|c|c|c|c|c|}
\hline Individual item & $\begin{array}{l}\text { Normative } \\
(n=123) \\
\text { Mean (SD) }\end{array}$ & $\begin{array}{l}\text { Clinical } \\
(n=124) \\
\text { Mean (SD) }\end{array}$ & $p$-values $^{\mathrm{a}}$ & Diff $^{b}$ & $95 \% \mathrm{Cl}$ & $\begin{array}{l}\text { Effect size } \\
\text { Cohens } d\end{array}$ \\
\hline 1. How do you find mealtimes with your child? & $6.04 \pm 1.04$ & $2.71 \pm 1.20$ & $<0.001$ & 3.33 & $3.05 ; 3.61$ & 3.01 \\
\hline 2. How worried are you about your child's eating? & $1.77 \pm 1.07$ & $5.61 \pm 1.44$ & $<0.001$ & 3.84 & $3.52 ; 4.16$ & 3.16 \\
\hline $\begin{array}{l}\text { 3. How much appetite (hunger) does your child } \\
\text { have? }\end{array}$ & $6.04 \pm 1.26$ & $3.06 \pm 1.33$ & $<0.001$ & 2.98 & $2.65 ; 3.30$ & 2.31 \\
\hline $\begin{array}{l}\text { 4. When does your child start refusing to eat during } \\
\text { mealtimes? }\end{array}$ & $5.98 \pm 1.24$ & $2.64 \pm 1.53$ & $<0.001$ & 3.35 & $3.00 ; 3.70$ & 2.46 \\
\hline $\begin{array}{l}\text { 5. How long do mealtimes take for your child } \\
\text { (in minutes)? }\end{array}$ & $2.11 \pm 0.68$ & $2.79 \pm 1.30$ & $<0.001$ & 0.68 & $0.42 ; 0.94$ & 0.76 \\
\hline 6. How does your child behave during mealtimes? & $2.00 \pm 1.02$ & $4.82 \pm 1.29$ & $<0.001$ & 2.83 & $2.53 ; 3.12$ & 2.49 \\
\hline $\begin{array}{l}\text { 7. Does your child gag or spit or vomit with certain } \\
\text { types of food? }\end{array}$ & $1.46 \pm 0.90$ & $3.04 \pm 1.87$ & $<0.001$ & 1.58 & $1.21 ; 1.94$ & 1.27 \\
\hline $\begin{array}{l}\text { 8. Does your child hold food in his/her mouth } \\
\text { without swallowing it? }\end{array}$ & $6.46 \pm 1.05$ & $5.10 \pm 1.85$ & $<0.001$ & 1.37 & $0.99 ; 1.74$ & 1.02 \\
\hline $\begin{array}{l}\text { 9. Do you have to follow your child around or use } \\
\text { distractions (toys, TV) so that your child will eat? }\end{array}$ & $1.94 \pm 1.40$ & $5.23 \pm 1.89$ & $<0.001$ & 3.29 & $2.87 ; 3.71$ & 2.06 \\
\hline 10. Do you have to force your child to eat or drink? & $6.18 \pm 1.19$ & $3.44 \pm 1.85$ & $<0.001$ & 2.74 & $2.35 ; 3.12$ & 1.91 \\
\hline $\begin{array}{l}\text { 11. How are your child's chewing (or sucking) } \\
\text { abilities? }\end{array}$ & $1.36 \pm 0.92$ & $2.59 \pm 1.89$ & $<0.001$ & 1.23 & $0.86 ; 1.60$ & 0.98 \\
\hline 12. How do you find your child's growth? & $6.21 \pm 1.32$ & $3.37 \pm 1.88$ & $<0.001$ & 2.84 & $2.43 ; 3.25$ & 1.85 \\
\hline $\begin{array}{l}\text { 13. How does your child's feeding influence your } \\
\text { relationship with him/her? }\end{array}$ & $6.54 \pm 0.77$ & $4.35 \pm 1.80$ & $<0.001$ & 2.19 & $1.84 ; 2.54$ & 1.93 \\
\hline $\begin{array}{l}\text { 14. How does your child's feeding influence your } \\
\text { family relationships? }\end{array}$ & $1.40 \pm 0.90$ & $3.67 \pm 1.69$ & $<0.001$ & 2.26 & $1.92 ; 2.60$ & 1.91 \\
\hline Total score & $24.58 \pm 8.02$ & $59.07 \pm 9.84$ & $<0.001$ & 34.50 & $32.24 ; 36.75$ & 3.86 \\
\hline
\end{tabular}

$t$-test for independent samples, two-tailed $p$-values: $p<0.05, p<0.01$, and $p<0.001$, data presented as mean \pm SD, Cohens d: $0.2-$ small effect size, 0.5 - medium, $0.8-$ large, $95 \%$ Cl: $95 \%$ confidence intervals, ${ }^{a}$ independent $t$-test two-tailed: item 1: $t(240)=23.35$, item 2: $t(227)=23.80$, item 3: $t(245)=18.07$, item 4: $t(236)=18.91$, item 5: $t(185)=5.19$, item $6: t(233)=19.01$, item $7:$ $t(177)=8.47$, item $8: t(195)=7.14$, item 9: $t(227)=15.55$, item 10: $t(210)=13.84$, item 11: $t(178)=6.53$, item 12: $t(220)=13.75$, item 13: $t(167)=12.48$, item 14: $t(188)=13.13$, total score: $t(245)=30.18$, between patient group and control group, ${ }^{b}$ mean differences in MCH-FS scores between clinical and normative group

(two-tailed), indicating a high level of stability for the total score of the tool. Correlation coefficients for the individual items of the $\mathrm{MCH}-\mathrm{FS}$ ranged from 0.89 to 1.00 in the clinical group and from 0.77 to 0.98 in the normative group, at $p<0.001$ (two-tailed).

\section{DISCUSSION}

The current study confirms that the MCH-FS is a valid and reliable screening tool for easy and quick identification of potential feeding problems among children. The Polish version of the scale has very good internal consistency with a high Cronbach's a (0.93), similarly to the original scale (0.85), the Thai version $(0.84)$, the Dutch version (0.84), and the Portuguese version (0.90). The $\mathrm{MCH}-\mathrm{FS}$ discriminates significantly between children with feeding difficulties and without feeding difficulties in total score, and in all 14 items. These results are similar to the other studies, suggesting also the universality of the tool regardless of the culture in which it is implement- ed. The age of the recruited children showed a significant difference between the clinical group and the normative group, which confirmed our predictions that parents of children with feeding difficulties identify the problem much earlier and report it to a specialist (in the clinical group more younger children were recruited).

Although age, weight, and length were significantly different between the two groups, similar results were demonstrated in the original validation of the MCH-FS [2]. The weight and length differences could be related to the child's prolonged feeding difficulties, such as partial or full food refusal, which might lead to impaired nutritional status. Among the clinical group, 20 children were diagnosed with nutritional impairment ( $>-2 \mathrm{SD})$.

In the current study PCA indicated two factors. Factor 1 includes constructs like: a) mealtime behaviour, b) family relations, c) parental concern, d) appetite, and e) most of the compensatory strategies. Factor 2 includes: a) oral sensory, b) oral motor, c) oral sensory, oral motor, mealtime behaviour, and d) compensatory strategy regard- 
TABLE 3. Principal component analysis of the Montreal Children's Hospital Feeding Scale (MCH-FS) for the whole sample $(n=247)$

\begin{tabular}{|c|c|c|c|c|c|}
\hline \multirow[t]{2}{*}{ Factors and items } & \multirow[t]{2}{*}{ Construct } & \multirow[t]{2}{*}{ Mean } & \multirow[t]{2}{*}{ Skewness } & \multicolumn{2}{|c|}{ Rotated factor loading } \\
\hline & & & & Factor 1 & Factor 2 \\
\hline \multicolumn{6}{|l|}{ Factor 1} \\
\hline 1. How do you find mealtimes with your child? & Parental concern & 4.37 & 0.12 & $\underline{0.85}$ & 0.37 \\
\hline 2. How worried are you about your child's eating? & Parental concern & 3.70 & 0.14 & $\underline{0.84}$ & 0.33 \\
\hline 12. How do you find your child's growth? & Parental concern & 4.79 & 0.50 & $\underline{0.61}$ & 0.34 \\
\hline 3. How much appetite (hunger) does your child have? & Appetite & 4.55 & 0.12 & $\underline{0.79}$ & 0.26 \\
\hline $\begin{array}{l}\text { 4. When does your child start refusing to eat during } \\
\text { mealtimes? }\end{array}$ & Appetite & 4.30 & 0.21 & $\underline{0.84}$ & 0.18 \\
\hline $\begin{array}{l}\text { 9. Do you have to follow your child around or use } \\
\text { distractions (toys, TV) so that your child will eat? }\end{array}$ & Compensatory strategies & 3.59 & 0.26 & $\underline{0.66}$ & 0.35 \\
\hline 10. Do you have to force your child to eat or drink? & Compensatory strategies & 4.81 & 0.48 & $\underline{0.76}$ & 0.25 \\
\hline 6. How does your child behave during mealtimes? & Mealtime behaviour & 3.42 & 0.25 & $\underline{0.89}$ & 0.31 \\
\hline $\begin{array}{l}\text { 13. How does your child's feeding influence your } \\
\text { relationship with him/her? }\end{array}$ & Family relations & 5.44 & 0.93 & $\underline{0.69}$ & 0.16 \\
\hline $\begin{array}{l}\text { 14. How does your child's feeding influence your } \\
\text { family relationships? }\end{array}$ & Family relations & 2.53 & 0.15 & -0.77 & 0.14 \\
\hline \multicolumn{6}{|l|}{ Factor 2} \\
\hline $\begin{array}{l}\text { 5. How long do mealtimes take for your child } \\
\text { (in minutes)? }\end{array}$ & Compensatory strategies & 2.45 & 1.15 & 0.29 & $\underline{0.30^{\mathrm{a}}}$ \\
\hline $\begin{array}{l}\text { 7. Does your child gag or spit or vomit with certain } \\
\text { types of food? }\end{array}$ & Oral sensory & 2.25 & 1.27 & 0.35 & $\underline{0.62}$ \\
\hline $\begin{array}{l}\text { 11. How are your child's chewing (or sucking) } \\
\text { abilities? }\end{array}$ & Oral motor & 1.98 & 1.83 & 0.13 & $\underline{0.81}$ \\
\hline $\begin{array}{l}\text { 8. Does your child hold food in his/her mouth without } \\
\text { swallowing it? }\end{array}$ & $\begin{array}{l}\text { Oral sensory, oral motor, } \\
\text { mealtime behaviour }\end{array}$ & 5.78 & 1.31 & 0.20 & $\underline{0.76}$ \\
\hline
\end{tabular}

Factor loadings above 0.30 are marked in bold, and the highest value is underlined. ${ }^{a}$ Rotated factor loading for question $5=0.301$

ing the duration of the mealtime. Factor 1 ("Mealtime behaviours and their consequents") seem to represent the child's mealtime behaviours and parental concerns regarding their child's eating. Factor 2 ("Oral-motor-sensory problems") seems to describe mostly the child's motor-oral-sensory problems and the duration of the child's mealtime (item 5). Item 5 in the original version of the $\mathrm{MCH}-\mathrm{FS}$ was categorised as the compensator strategies, but it could also be related to the child's lack of oral-motor abilities, which might explain the low factor loadings of this question (0.291 for factor 1 and 0.301 for factor 2). Children who gag or vomit during meals, spit food out, have problems with chewing/sucking, or hold the food in the month might need more time to finish their meal. These two factors explain $61.82 \%$ of the variance. The results of the factor analysis reported in the Dutch validation of the MCH-FS [5] yielded inconclusive results, where the polychoric parallel analysis (PA) based on minimum rank factor analysis (MRFA) indicated one factor (79\% of the common variance), and PA based on PCA indicated two factors (90\% of the common variance). Results of the factor analysis from the Thai [3] and Portuguese validations [4] showed three components of the scale, explaining $52.3 \%$ and $73 \%$ of the total variance, respectively. Additionally, the factor analysis of the original $\mathrm{MCH}$-FS resulted in one factor, explaining $48 \%$ of the variance [2].

The MCH-FS demonstrates excellent accuracy where the area under the ROC curve is 0.99 . Similar results were demonstrated for the original scale (0.85) and for the Thai version $(0.86)$. The discrimination score for the current study was 46 (sensitivity $89.5 \%$ and specificity $99.2 \%$ ), where for original version it was 45 (sensitivity $87.3 \%$ and specificity $82.3 \%$ ), and for the Thai version - 40 (sensitivity $72 \%$ and specificity $80.67 \%$ ). A cut-off point of 46 should provide a low rate of misdiagnosis of feeding problems. The higher the total score in the MCH-FS, the more severe the symptoms of feeding difficulties.

\section{STRENGTHS AND LIMITATION}

The strength of the study was a rigorous process of translation, adaptation, and validation, with properly used statistical methods. Moreover, the classification of feeding difficulties was done independently by two specialists: a gastroenterologist and a psychologist. Our study 
was conducted as a single-centre study, which limits the generalisation of its results to other populations. However, the clinic from which parents of children with feeding difficulties were recruited is a centre with a large catchment area, which means that parents were not only from Warsaw. The results of our study are concurrent with other validations.

\section{CONCLUSIONS}

The Polish version of the MCH-FS is a reliable and valid tool for rapid identification of feeding difficulties among children from six months up to six years old. Early identification of these difficulties is crucial for the rapid implementation of therapeutic procedures to avoid possible consequences.

\section{ACKNOWLEDGEMENTS}

The authors wish to thank Urszula Malinowska for providing statistical help and advice.

\section{DISCLOSURE}

The authors declare no conflict of interest.

\section{REFERENCES}

1. Sanchez K, Spittle AJ, Allinson L, Morgan A. Parent questionnaires measuring feeding disorders in preschool children: a systematic review. Dev Med Child Neurol 2015; 57: 798-807.

2. Ramsay M, Martel C, Porporino M, Zygmuntowicz C. The Montreal Children's Hospital Feeding Scale: A brief bilingual screening tool for identifying feeding problems. Paediatr Child Health 2011; 16: 147-151.

3. Benjasuwantep B, Rattanamongkolgul S, Ramsay M. The Thai version of the Montreal Children's Hospital Feeding Scale (MCH-FS): psychometric properties. J Med Assoc Thai 2015; 98: 163-169.

4. Lopes AC, Guimarães I, Afonso C. Montreal Children's Hospital Feeding scale: Tradução e contribuição para a validação em português europeu. Revista Portuguesa de Terapia da Fala (APTF) 2015; 3: 5-15.

5. van Dijk M, Timmerman ME, Martel C, Ramsay M. Towards the development of a Dutch screening instrument for the detection of feeding problems in young children. Neth J Psychol 2011; 66: 112-119.

6. Sousa VD, Rojjanasrirat W. Translation, adaptation and validation of instruments or scales for use in cross-cultural health care research: a clear and user friendly guideline. J Eval Clin Pract 2011; 17: 268-274.

7. Bujang MA, Baharum N. A simplified guide to determination of sample size requirements for estimating the value of intraclass correlation coefficient: a review. Arch Orofac Sci 2017; 12: 1-11. 
APPENDIX 1. Polish version of the Montreal Children's Hospital Feeding Scale (Skala MCH związana z karmieniem dziecka - wersja polska)

Centre universitaire de santé McGill McGill University Health Centre
The Montreal Children's Hospital - Pediatric Feeding Program

Skala MCH związana z karmieniem dziecka - wersja polska

Dzieci: od 6. miesiąca (otrzymujące dietę przecieraną) do 6. roku życia

Data: Imię dziecka:

Proszę o zaznaczenie odpowiedniej cyfry przy każdym pytaniu. Proszę zwrócić uwagę, że znaczenia cyfr różnią się między sobą - każdej cyfrze może odpowiadać inna wartość. Proszę uważnie przeczytać każde z pytań. Dziękuję.

\begin{tabular}{|c|c|c|c|c|c|c|c|}
\hline $\begin{array}{l}\text { 1. Jak ocenia Pan/Pani przebieg posiłku swojego } \\
\text { dziecka? }\end{array}$ & $\begin{array}{c}1 \\
\text { Bardzo trudny }\end{array}$ & 2 & 3 & 4 & 5 & 6 & $\begin{array}{c}7 \\
\text { Łatwy }\end{array}$ \\
\hline $\begin{array}{l}\text { 2. Jak bardzo martwi się Pan/Pani przebiegiem } \\
\text { posiłków swojego dziecka? }\end{array}$ & $\begin{array}{c}1 \\
\text { Nie martwię się }\end{array}$ & 2 & 3 & 4 & 5 & 6 & $\begin{array}{l}7 \\
\text { Bardzo się } \\
\text { martwię }\end{array}$ \\
\hline $\begin{array}{l}\text { 3. Jak ocenia Pan/Pani apetyt (uczucie głodu) } \\
\text { swojego dziecka? }\end{array}$ & $\begin{array}{l}1 \\
\text { Nigdy nie jest } \\
\text { głodne }\end{array}$ & 2 & 3 & 4 & 5 & 6 & $\begin{array}{c}7 \\
\text { Dobry apetyt }\end{array}$ \\
\hline $\begin{array}{l}\text { 4. W którym momencie podczas posiłku Pana/Pani } \\
\text { dziecko zaczyna odmawiać jedzenia? }\end{array}$ & $\begin{array}{c}1 \\
\text { Na początku }\end{array}$ & 2 & 3 & 4 & 5 & 6 & $\begin{array}{l}7 \\
\text { Na końcu } \\
\text { posiłku }\end{array}$ \\
\hline $\begin{array}{l}\text { 5. Jak długo trwają posiłki Pana/Pani dziecka } \\
\text { (w minutach)? }\end{array}$ & $\begin{array}{c}1 \\
1-10\end{array}$ & $\begin{array}{c}2 \\
11-20\end{array}$ & $\begin{array}{c}3 \\
21-30\end{array}$ & $\begin{array}{c}4 \\
31-40\end{array}$ & $\begin{array}{c}5 \\
41-50\end{array}$ & $\begin{array}{c}6 \\
51-60\end{array}$ & $\begin{array}{c}7 \\
> \\
>0\end{array}$ \\
\hline $\begin{array}{l}\text { 6. Jak ocenia Pan/Pani zachowanie swojego dziecka } \\
\text { podczas posiłków? }\end{array}$ & $\begin{array}{l}1 \\
\text { Zachowuje się } \\
\text { dobrze }\end{array}$ & 2 & 3 & 4 & 5 & 6 & $\begin{array}{c}7 \\
\text { Wybrzydza, } \\
\text { awanturuje się }\end{array}$ \\
\hline $\begin{array}{l}\text { 7. Czy Pana/Pani dziecko dławi się, krztusi, wypluwa } \\
\text { lub wymiotuje przy niektórych rodzajach } \\
\text { pokarmów? }\end{array}$ & $\begin{array}{l}1 \\
\text { Nigdy }\end{array}$ & 2 & 3 & 4 & 5 & 6 & $\begin{array}{c}7 \\
\text { Zazwyczaj }\end{array}$ \\
\hline $\begin{array}{l}\text { 8. Czy Pana/Pani dziecko przetrzymuje pokarm } \\
\text { w jamie ustnej bez jego połykania? }\end{array}$ & $\begin{array}{c}1 \\
\text { Zazwyczaj }\end{array}$ & 2 & 3 & 4 & 5 & 6 & $\begin{array}{l}7 \\
\text { Nigdy }\end{array}$ \\
\hline $\begin{array}{l}\text { 9. Czy musi Pan/Pani chodzić za swoim dzieckiem } \\
\text { lub odwracać jego uwagę (zabawki, telewizor), } \\
\text { żeby dziecko jadło? }\end{array}$ & $\begin{array}{l}1 \\
\text { Nigdy }\end{array}$ & 2 & 3 & 4 & 5 & 6 & $\begin{array}{c}7 \\
\text { Zazwyczaj }\end{array}$ \\
\hline $\begin{array}{l}\text { 10. Czy musi Pan/Pani zmuszać swoje dziecko } \\
\text { do jedzenia lub picia? }\end{array}$ & $\begin{array}{c}1 \\
\text { Zazwyczaj }\end{array}$ & 2 & 3 & 4 & 5 & 6 & $\begin{array}{c}7 \\
\text { Nigdy }\end{array}$ \\
\hline $\begin{array}{l}\text { 11. Jak ocenia Pan/Pani umiejętności żucia (lub } \\
\text { ssania) swojego dziecka? }\end{array}$ & $\begin{array}{c}1 \\
\text { Dobre }\end{array}$ & 2 & 3 & 4 & 5 & 6 & $\begin{array}{c}7 \\
\text { Bardzo słabe }\end{array}$ \\
\hline $\begin{array}{l}\text { 12. Jak ocenia Pan/Pani wzrastanie (masę ciała, } \\
\text { wzrost) swojego dziecka? }\end{array}$ & $\begin{array}{l}1 \\
\text { Rozwija się } \\
\text { słabo }\end{array}$ & 2 & 3 & 4 & 5 & 6 & $\begin{array}{c}7 \\
\text { Rozwija się } \\
\text { dobrze }\end{array}$ \\
\hline $\begin{array}{l}\text { 13. Jak karmienie dziecka wpływa na relacje } \\
\text { Pana/Pani z dzieckiem? }\end{array}$ & $\begin{array}{c}1 \\
\text { Bardzo } \\
\text { negatywnie }\end{array}$ & 2 & 3 & 4 & 5 & 6 & $\begin{array}{l}7 \\
\text { Wcale nie } \\
\text { wpływa }\end{array}$ \\
\hline $\begin{array}{l}\text { 14. Jak karmienie Pana/Pani dziecka wpływa } \\
\text { na relacje rodzinne? }\end{array}$ & $\begin{array}{c}1 \\
\text { Wcale } \\
\text { nie wpływa }\end{array}$ & 2 & 3 & 4 & 5 & 6 & $\begin{array}{c}7 \\
\text { Bardzo } \\
\text { negatywnie }\end{array}$ \\
\hline
\end{tabular}

